\title{
THE USE OF SCAFFOLDING TALK TECHNIQUE TO IMPROVE THE SECOND GRADE STUDENTS SPEAKING SKILL AT MTS MADANI PAOPAO GOWA
}

\author{
Fatur Rahmah \\ St. Nurjannah Yunus Tekeng \\ English Education Department of UIN Alauddin Makassar \\ rahmah.fatur@yahoo.co.id \\ Jannah.yustek@gmail.com
}

\begin{abstract}
Abstrack: This research aimed to determine the use of scaffolding talk technique to improve the speaking skill. Therefore, the problem statement was only one, that is "Is using scaffolding talk technique effective to improve the speaking skill of the second grade students of MTs Madani PaoPao Gowa?" .The study was using quasi experimental design with non-equivalent control group design. The study involved 58 students of the second Grade students of MTs Madani PaoPao that was taken by using purposive sampling technique. The data were analyzed using descriptive statistic (frequency, mean score, and standard deviation) and inferential statistic (independent sample t-test). The result of this research showed that the mean score in the post-test for experimental class was 48.59 and for the control class was 35.52. Based on the calculation of the $\mathrm{t}$-test, the result showed there was a significant difference between the mean score of both post-test. This means that scaffolding talk technique was effective to improve the students' speaking skill. Why scaffolding talk was effective to improve the speaking skill because this technique emphasize the use of English as the language model of interaction in all learning activities in English class. Based on te result of calculation of t-test showed that the difference in the average value of the ability to speak English of both treatment groups was significant with the t-test 4.63 , and the value oft-table was smaller than 2.00 . These results indicate that the scaffolding talk technique is more influential in students' ability to speak English.
\end{abstract}

Key Words: Scaffolding, Speaking Skill

\section{INTRODUCTION}

7 $\mathrm{n}$ English, there are four skills which should be mastered by language learners; those are listening, speaking, reading and writing. One of the skills that should be mastered

by the students is speaking. Speaking skill is the most common and important means of providing communication among humans beings. Speaking is one of difficult skills, that is why the student feels bored to speak. To master this skill is not an easy thing because there are some language components as the tools for mastering it. Brown and Yule in Tika Rahmawati (2014) stated that "learning to talk in the foreign language is often considered being one of the most difficult aspects of language learning for the teacher to help the students with". Many of the learners in a speaking class are reluctant speakers. The disability of the students to speak may lead them to be unable to express their ideas, feelings, thoughts even in a simple form of conversation. 
An ideal English class ought to use English in communication and conversation. Based on previous study at MTs Madani Paopao, most of students still used their mother tongue to ask or to give response to the teacher. Most of the students they have a problem to communicate or apply English orally. The low of speaking ability could be seen from the oral tests that are under average. The students are almost unintelligible, use the words wrongly, and show no sign of any grammatical understanding. It means they were in fair categories and their speaking was not good. In this case, teachers have to be creative in developing their teaching learning process to create good ambience, improve the student's speaking skill, pay attention to the elements of speaking and make the English lesson more exciting.

Teaching speaking is not an easy business. Tthe genaral problem that face by the students that were. First, the students have low speaking ability because they rarely practice English to communicate with the others and possible they do not know how to speaking in English. They always tought that speaking is very difficult. Second, it caused by the components of language something like are vocabulary, grammar, pronunciation, fluency and etc. Third, the difficulty of mastering it is also caused by the other factors and the factor is teaching technique. There are several teaching techniques that can be used to increase students speaking skill. The technique can be used that were role-plays, communication games, discussion, scaffolding talk. As a good teacher should be smart to choose an approach or technique of teaching that is suitable with the condition and the needs of the students. As a result, the goal of teaching and learning can be achieved.

The teacher has an important role for students. In this case, to make the classroom effective and efficient, a teacher should deliver and give instructions in English. The teacher has to choose the best technique to teach speaking. In this case the researcher tried to use a technique. That is scaffolding talk technique. Scaffolding talk are expressions of the teacher to interact or give instruction to his or her students in the classroom. In the scaffolding process, the teacher helped the student master a skill that the student is initially unable to acquire it independently. For example, the teacher gives assistance as give model first before students produce something. The teacher offers assistance that is beyond the student's ability. The teacher only helps the student with tasks that are just beyond his or her current ability. The teachers can be needed as the mediator and facilitatorin the teaching and learning procces.

Scaffolding talks provide help, support, guidance, model, facilities to build up an interaction at a target language structure over several turns. Initially in language learning, students may not be able to produce certain structures within single utterances, but may build them through interaction with other speaker. In short, it can be said that scaffolding talk is used to make students comprehend meaning, the teachers need to express the meaning step 
by step and to organize those steps in a linear fashion according to the socially acceptable structure. Besides, the teachers should be good models, good mediators, good facilitators and good guides in order that the learners can cross the bridge safely without any difficulties. The bridge here is the scaffolding itself in which the students have to pass it to reach desired expression. In Scaffolding represents the relationship of the learner with the teacher support in learning with assistance or support until the learning is mastered and becomes independent of support.

All of the above explanations create inspiration to the researcher to make an experimental research, because the researcher wanted to know the effectiveness of the implementation of scaffolding talk technique can improve students s peaking skill in second grade students of MTs Madani Paopao. Therefore, the researcher made an experimental research with under the title: "The Use of Scaffolding Talk Technique to Improve the Second Grade Students' Speaking Skill at MTs Madani PaoPao Gowa ”

Based on the background above, the problem statement in this study can be formulated as follows "Is the use of scaffolding talk technique effective to improve the speaking skill of the second grade students of MTs Madani PaoPao Gowa?.

\section{LITERATURE REVIEW}

Several studies had been conducted relating to teaching speaking, Irfan (2008) in his research, “ Increasing Students' Speaking Skill Through Based Learning Strategy at Second Grade of MA At-Tauffiq Lisu Barru”, concluded that teaching by using based learning strategy can develop the students' speaking ability. The result of his research showed that second grade students of MA At-Tauffiq Lisu Barru Regency had inadequate score in pretest. However, after doing the treatment their speaking ability got high score in post-test. The finding of his research showed that there was significant with the pre-test and post-test where the pre-test was $90.5 \%$ and the post-test was $97 \%$. It can be concluded that method was very effective to increasing the students' speaking ability.

Amelia Ali (2013) in her research, “"The Effectivenees of Guessing Games to Improve the Students' Speaking Skill at the Second Year of SMP PPM Darul Falah Enrekang“, concluded that teaching by using guessing games improving the students' speaking ability through guessing games can developed the students' speaking ability. The result of her research showed that second grade students of SMP PPM DarulFalahEnrekang had inadequate score in pre-test. However, after doing the treatment their speaking ability got high score in post-test. The finding of his research showed that there was significant with the pre-test and post-test where the pre-test was $63.26 \%$ and the post-test was $77.3 \%$. It can be conclude that method was very effective to increasing the students' speaking ability. 
Syarif (2014) in his research, 'Improvingthe Students' Speaking Ability of Second Grade Through Communicative Approach at Shekh Hasan Yamani Islamic Boarding School in Polman", concluded that teaching by using communicative approachcan developed the students' speaking ability. The result of his research showed that second grade students of Shekh Hasan Yamani Islamic Boarding School in Polman had inadequate score in pre-test. However, after doing the treatment their speaking ability got high score in post-test. The finding of his research showed that there was significant with the pre-test and post-test. He reported that communicative approach is effective to improve the students' speaking ability, particularly the second grade students' of Syekh Hasan Yamani Islamic Boarding School in Polman. Based on the interpretation of the researcher of the data findings, the researcher found where t-test value was higher than $\mathrm{t}$-table value; $8.03>2.05$.

In the researcher's point of view, the above related studies present complicated strategies in improving student's speaking skill. They had a similarity with this research because all of them had some objective to improve the students' speaking skill. In contrast, this research has difference with previous finding above, because it will be conducted by different strategy and procedure. A good strategy should present an easiest and a simplest one and it can reduce to the teacher in class activities as trigger student's creativities to independent learners. Finally, the researcher was tried to use a new technique namely scaffolding talk technique. This technique can helped students to improve speaking skill.

\section{Speaking}

Speaking skill is an ability to orally express opinion, thought, and feeling to other people both directly and indirectly. Speaking is an interactive process of constructing meaning that involves producing, receiving and processing information (Brown, 2004). Speaking was the skill that the students will be judged upon most in real-life situations. It was an important part of everyday interaction and most often the first impression of a person is based on his/her ability to speak fluently and comprehensively. So, as teachers have a responsibility to prepare the students as much as possible to be able to speak in English in the real world outside the classroom (Hornby 1995: 37). Speaking is the competence to express explain and convey thinking, feeling, and idea. Speaking ability means the ability to think. So it was very important because language is primarily speech. Oral communication is seen as a basic skill so it is needed. Not only serious treatment is needed in teaching but also a great effort in order to be able to master the skill. To most people, mastering the art of speaking was the single most important aspect of learning a second or a foreign language, and success was measured in term of the ability to carry out conversation in the language (Fauziati 2005: 126). In addition, she asserts that speaking was an interactive process of constructing meaning that involves producing, receiving and processing information. 
Fatur Rahmah \& St. Nurjannah Yunus Tekeng, The Use of Scaffolding Talk Technique...

\section{Types of Speaking Performances}

Types of speaking in this research based on Brown (2004:140) described some categories of speaking skill area. Those categories are as follows:1) Imitative, This category includes the ability to practice an intonation and focusing on some particular elements of language form. That is just imitating a word, phrase or sentence. The important thing here is focusing on pronunciation. In scaffolding, The teacher used drilling in the teaching learning process. The reason is by using drilling, students get opportunity to listen and to orally repeat some words. The imitative type in scaffolding in this research can be seen in drilling when the students try to imitating a word, phrase or sentence that given by the teacher direction. By using drilling, students get opportunity to listen and to orally repeat some words.2) Intensive, This is the students' speaking performance that is practicing some phonological and grammatical aspects of language. It usually places students doing the task in pairs (group work), for example, reading aloud that includes reading paragraph, reading dialogue with partner in turn etc. This type in scaffoldingin this research can be seen to the students pratice to reading dialogue with partner or doing the task in pairs. The students make a dialogue and practice with their partner. 3) Extensive, Teacher gives students extended monologues in the form of oral reports, summaries, and storytelling and short speeches. In scaffolding the students made the oral reports. Here the students try to make story telling.

\section{Characters of Successful Speaking}

When the students choose to learn a language, they are interested in learning to speak that language as fluently as possible. There are the characteristics of successful speaking: 1)Learners talk a lot, As much as possible of the period of time allocated to the activity is a fact occupied by learners talk. 2) Participation, Classroom discussion is not dominated by a minority of talk active participants. It means that all students get a chance to speak and participate in class. 3) Motivation is high, All students have enthusiasm to speak in class. As Nunan (1991:39) states that the successful in speaking is measured through someone ability to carry out a conversation in the language.

\section{Scaffolding Talk}

Scaffolding theory was introduced in the late 1950s by Jerome Bruner, a cognitive psychologist. He used the term to describe children's oral language acquisition that was helped by their parents when they first begin to speak. Scaffolding as a teaching strategy originates from Lev Vygotsky's sociocultural theory and his concept of the zone of proximal development (1978) represents the relationship of the learner with the teacher support in learning with assistance or support until the learning is mastered and becomes independent of support. "The zone of proximal development is the distance between what children can do by themselves and the next learning that they can be helped to achieve with competent assistance" (Raymond in Tika Rahmawati, 2014). 
Inherent in scaffolding from Lev Vygotsky's (1978) idea of Zone of proximal development Vygotsky suggested that there are two part of learner's developmental level. 1. The actual developmentallevel; the zone of proximal development is "the distance between the actual developmental level as determined by independent problem solving. It is the differences between the students actual development level determined by their capability to master the task independently 2. The potential developmental level; as determined through problem solving under the help of teacher, adult guidance or in collaboration with more capable peers (Jauhar 2011:39). The ability to learn through instruction and help adults make students can understand and do a lot of things than if the students just learning independently.

In accordance with scaffolding talk theories mentioned above, it is also important to unfold The procedure of scaffolding talk according Vygotsky and Bruner in Corden (2000 :

10) are :

1) Teacher explain the materials,

2) Giving example of the task to the students related with the materials,

3) Modeling, showing students examples of work produce by teacher, provide assistance, guide, giving clues which provoke the students toward independent learning,

4) Demonstrating, illustrating the procedures from the teacher through work product, supporting the students as they learn and practice procedures,

5) Encourage the students to learn complete their task independently.

\section{RESEARCH METHOD}

\section{Population and Sample}

Population is all subject of research (Arikunto2013:173). The population of this research was all the second students of the second grade students of MTs MadaniPaopao. There were three classes take as investigation group which consist of 29 students per class. The total of population is 87 students. In class VIII A, consist of 8 girls and 21 boys. In class VIIIB, consist of 15 girls and 14 boys. In class VIIIC, consist of 17 girls and 12 boys.

Sample is a part or represantive of the population which is searching (Arikunto 2010). The researcher applied the purposeve sampling technique in which two classes taken as sample. In this case, the researcher choose class VIII/A as the experimental class and class VIII/B as the control class. Each of the classes consists of 29 students; therefore the total numbers of students are 58 . These classes were divided into experiment and control class.

\section{Procedure of Collecting Data}

Before implementing a research, the researcher first of all was made research design and that cover as follows: 
Fatur Rahmah \& St. Nurjannah Yunus Tekeng, The Use of Scaffolding Talk Technique...

\section{Provide Planning}

In planning, the researcher was prepared materials, lesson plan, and list of student's name and scoring.

\section{Giving Pre-test}

Before giving a treatment, the researcher gives a speaking test to know the students' speaking ability. In this case, the researcher used speaking test. This test was using to know the students' prior speaking ability before they are giving a treatment.

\section{Giving Treatments}

The treatments given to the students after giving the pre-test. Treatment was activities from the researcher to the students by giving teaching learning in the class by using scaffolding talk technique. This technique was kind of way that can increase students' speaking skill. The researcher does the teaching learning process by giving explanation about scaffolding talk technique and how to do assignment well. The control class treated by using conventional strategy. The Procedures of treatment were the researcher entering to the class and doing teaching-learning process as the schedule, In the process of teaching and learning the researcher given the meaning of words one by one on order to be easy done with scaffolding talk technique, before researcher ended the teaching learning process, the teacher give the homework to students. The time used about 30 minutes.

\section{Giving a Post-test}

The post-test given to the sample after treatments; the purpose was to know the students' achievement in speaking skill after applying scaffolding talk technique. The type of the test was speaking test.

\section{Technique of Data Analysis}

The data was collected through the test by using inferential statistic percentage. Score was also used to know the students' ability in speaking skill. The steps under taken in quantitative analysis employing the following formulas:

\section{Scoring the student's answer by using the following formula}

$$
\begin{aligned}
& \text { Score }=\frac{\text { Students' correct answer }}{\text { Total number of item }} \times 100 \\
& \text { (adopted from depdikbud in Sukirman 2010:36) }
\end{aligned}
$$


Classifying the score answer into the following criteria

\begin{tabular}{|c|c|}
\hline Scale & Classification \\
\hline $95-100$ & Excellent \\
\hline $85-94$ & Very good \\
\hline $75-84$ & Good \\
\hline $65-74$ & Fairly good \\
\hline $55-64$ & Good \\
\hline $45-54$ & Poor \\
\hline $0-44$ & Very poor \\
\hline
\end{tabular}

Table 3.1 students' score classification (Depdikbud in Nur: 2011)

Calculating the mean score of the students' answer by using the following formula:

$$
\begin{array}{ll}
\bar{X}=\frac{\sum X}{N} & \\
\text { Where, } \bar{X} & =\text { mean score } \\
\sum_{\mathrm{N}}^{\mathrm{X}} & =\text { the sum of all scores } \\
& =\text { the total number of subject }
\end{array}
$$

(Gay 2006, p: 320)

Finding out the standard deviation by applying this formula:

Where:

$$
S D=\sqrt{\begin{array}{c}
S S \\
N-1
\end{array}}, \text { where } S S=\sum \mathrm{X}^{2}-\frac{\left(\sum X\right)^{2}}{N 1}
$$

$\mathrm{SD} \quad=$ Standard Deviation

SS $\quad=$ The sum of square

$\mathrm{N} \quad=$ Total number of the subjects

$\sum X^{2}=$ The sum of all square; each score is squared and all the squares are added up $\left(\sum X\right)^{2}=$ The square of the sum; all the scores are added up and the sum is square, total.

(Gay 2006, p: 321)

The formula used in finding out the difference between students' score in pre-test and post-test.

Where:

$$
t=\frac{\overline{\mathrm{x}} 1-\overline{\mathrm{x}} 2}{\sqrt{\left(\frac{\mathrm{SS} 1+\mathrm{SS} 2}{\mathrm{n} 1+\mathrm{n} 2-2)\left(\frac{1}{\mathrm{n} 1}+\frac{1}{\mathrm{n} 2}\right)}\right.}}
$$

$\mathrm{t}=$ Test of significance

$\overline{\mathbf{x}}_{1}=$ Mean score of experimental group 
$\overline{\mathrm{x}}_{2}=$ Mean score of controlled group
$\mathrm{SS}_{1}=$ Sum square of experimental group
$\mathrm{SS}_{2}=$ Sum square of controlled group
$\mathrm{n}_{1}=$ Number of students of experimental group
$\mathrm{n}_{2}=$ Number of students of controlled group.

(Gay 2006, p: 349)

The result of the $t$ test were compared with $t$ table to see if there was a significant difference between the experimental class and controlled class on the other hand, the experiment was effective.

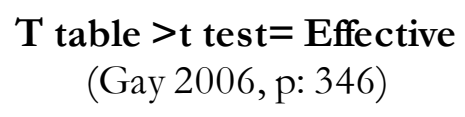

\section{Operasional Defenition of Terms}

Scaffolding talk technique is a technique of teaching where the teacher speaking in the classroom to interact with students to provide some assistance in the early stages of learning after that by reducing such assistance gradually by giving more responsibility to the students so that the students can do it independently. The assistance can include clear instructions in performing a task of the teacher or it can also be in the forms of encouragement, guidance.

Speaking skill is an ability to express opinion orally, thought, and feeling to other people both directly and indirectly. In this research, The speaking skill is based on three aspects of speaking which are fluency, accuracy and comprehensibility. This skill can be asserts through scaffolding talk technique.

\section{FINDINGS AND DISCUSSION}

\section{Findings}

Findings of the study deal with the presentation rate of the students' score obtained from the test to find the mean score, standard deviation, test of significance, and hypothesis testing.

\section{Result of Students' Pre Test in Experimental and Controlled Class}

Table of the result of students' pre-test in experimental class are shown in the appendix I. It showed that the lowest score of pre-test in experimental class is sixteen point six for two students and the highest is fifty-five point five for one student. The lowest scoring of the students when they spoke in the pre-test was one score for the fluency, one score for the accuracy and one score for the comprehensibility. The highest score that the student had when she spoke in pre test was three for fluency, four for accuracy, and three for comprehensibility.

For the controlled class, the data are shown in the appendix I. It showed that the lowest score in the pretest is twenty-two point two for two students and the highest score is fifty- 
five point five for one student. The lowest of the students when they spoke in the pre test was two scores for the fluency, one score for the accuracy and one score for the comprehensibility. The highest score that the students had when they spoke in pre-test was four for fluency, three for accuracy, and three for comprehensibility. Before conducting the research, it was important to determine the mean score for both classes and the t-test to measure students' basic knowledge, to find out whether the result is significant or not and to be able to make sure whether the research can be continued or not. The Students' mean score for both classes and the t-test in the pretest are shown in the following table.

\begin{tabular}{|c|c|c|c|}
\hline Class & Mean Score & t-test & t-table \\
\hline Experimental Class & 33.83 & \multirow{2}{*}{0.44} & \multirow{2}{*}{2.00} \\
\hline Controlled Class & 34.79 & & \\
\hline
\end{tabular}

Table 4.1 Students' result of Mean Score, T-test, and T-table

The table 4.1 showed that the mean score of the students in the experimentalclass was quite lower than in the controlled class in which the gap between them was only 0.44 . The result of the mean score described that the difference of the students' basic knowledge is almost equal. In addition, $t$-test of the pretest between experimental and controlled class was 0.44 and the t-table was 2.00 .

Making a conclusion about students' score is by comparing the t-test and the t-table. When the result of the $t$-test is smaller than the t-table, it means that there was no significance among the result of the students' basic knowledge and it was appropriate for the research to be continued. The table 4.1 above showed that there was no significance between students' score in the pre-test because the t-test was smaller than the t-table $(0.44<2.00)$ so the research can be continued.

\section{The Result of Students' Post test in Experimental and Controlled Class}

Table of the result of students' post-test in experimental and controlled class (See Appendix II) demonstrated the score of post-test in experimental and control class. For the experimental class, the lowest score in the post-test was sixteen point six for two students and the highest one is eighty-three point three for two students. The lowest scoring students when they spoke in the post-test were one score for the fluency, one score for the accuracy and one score for the comprehensibility. The highest score that the students had when they spoke in post-test was five for fluency, five for accuracy, and five for comprehensibility. In addition, for controlled class, the lowest score was sixteen point six and the highest was sixtyone point one. The lowest scoring students when they spoke in the post-test were one score for the fluency, one score for the accuracy and one score for the comprehensibility. On the other hand, the highest score that the student had when she spoke in post-test was four for 
fluency, three for accuracy, and four for comprehensibility. Based on the results above, it was clear that the scaffolding talk technique has a positive impact to improve students' speaking skill especially for fluency, accuracy, and comprehensibility.

For the total score, the table of students' post-test showed that experimental class got 1409 and controlled class got 1030. It indicated that total score in experimental class was much higher than controlled class. Comparing with the results in pre-tests, the experimental class showed the high enhancement, on the other hand, the controlled class scores were decreased.

\section{Students' Classification Score in Post-test for Experimental and Controlled Class}

In the experimental class, there were 15 students or (51.7\%) classified into very poor, 6 students or $20.6 \%$ were classified into fair, 2 students or $6.9 \%$ were classified into fairly good, and 1 students or $3.4 \%$ were classified into good.

For controlled class, there were 26 students or $89.6 \%$ classified into very poor, 1 students or $3.4 \%$ classified into fair and 2 students or $6.9 \%$ classified into poor. The data are shown in the following table:

\begin{tabular}{|c|c|c|c|c|c|c|}
\hline \multirow[t]{2}{*}{ No. } & \multirow[t]{2}{*}{ Scale } & \multirow[t]{2}{*}{ Classification } & \multicolumn{2}{|c|}{$\begin{array}{c}\text { Experimental } \\
\text { Class }\end{array}$} & \multicolumn{2}{|c|}{ Controlled Class } \\
\hline & & & $\bar{F}$ & $\%$ & $\mathrm{~F}$ & $\%$ \\
\hline 1 & $95-100$ & Excellent & - & - & - & - \\
\hline$\overline{2}$ & $85-94$ & Very Good & $\begin{array}{l} \\
\end{array}$ & $\begin{array}{l}- \\
\end{array}$ & - & $\begin{array}{l}- \\
\end{array}$ \\
\hline 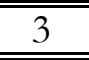 & $75-84$ & Good & 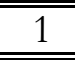 & 3.4 & $\overline{-}$ & $\overline{-}$ \\
\hline 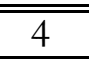 & $65-74$ & Fairly Good & 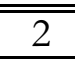 & 6.9 & - & - \\
\hline 5 & $55-64$ & Fair & 6 & 20.6 & 1 & 3.4 \\
\hline 6 & $45-54$ & Poor & 5 & 17.2 & 2 & 6.9 \\
\hline 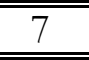 & (0-44 & Very Poor & 15 & 51.7 & 26 & 89.6 \\
\hline & & TOTAL & 29 & 100 & 29 & 100 \\
\hline
\end{tabular}

\section{Table 4.2 students' classification score percentile}

In summary, the data showed in the table indicates that students in experimental class have better enhancement than controlled class. For both classes, there was nobody classified into neither excellent nor very good but the difference was shown in the other classification of the score; Good, Fairly Good, Fair, and Very Poor. There were two students get good in experimental class because they showed a good speaking skill through the post test but there were no students get good in the controlled class. The two students who got the good great were very good in fluency, they only an effort time to search for words nevertheless, smooth delivery overall speaking and only a few unnatural pauses. As their accuracy, they only had a few minor grammatical and lexical errors but most utterances are correct. As their comprehensibility, the speaker's intention and general meaning are fairly clear and only a few interruptions by the listener for the sake of clarification are necessary. 
In fairly good, six students in experimental class no one in controlled class who get the grade. For the fairly good fluency in experimental class, the students had to make an effort too much of the time, often has to search the desire meaning. Rather halting delivery and fragmentary, and range of expression often limited even though there were also students who although had to make an effort and search for words, there were not too many unnatural pauses, fairly smooth delivery mostly. Occasionally fragmentary but succeeded in conveying the general meaning, fair range of expression. As for their accuracy, pronunciations were still moderately influenced by the mother-tongue but no serious phonological errors. A few grammatical and lexical errors but only one or two major errors cause confusion but there were also students' pronunciation is influenced by the mother tongue but only a few serious phonological errors. A few grammatical and lexical errors, some of which cause confusion. As for their comprehensibility, most of what the students say was easy to follow. Theirintentions were always clear but several interruptions are necessary to help them to convey the message or to seek clarification.

There were three students in experimental class and two students in controlled class classified into fair, and there are six students in experimental class classified into very poor while in the controlled class, there are fifteen students classified in it. the data showed that the experimental is better in speaking rather than in the controlled class. Therefore, the scaffolding talk technique is has a positive result of enhancement in speaking especially in fluency, accuracy and comprehensibility.

Furthermore, in experimental class, the classification from fairly good to very poor is $86.6 \%$ while the controlled class is $100 \%$. It indicated that students who got high classification are much higher in experimental class than in controlled class.

\section{Mean Score and Standard Deviation}

The following table presented the mean score and standard deviation of the experimental class and controlled class.

The mean score and standard deviation in the post-test of the experimental class and controlled class:

\begin{tabular}{|c|c|c|}
\hline Class & Mean Score & Standard Deviation \\
\hline Experimental & 48.59 & 13.36 \\
\hline Controlled & 35.52 & 9.34 \\
\hline
\end{tabular}

Table 4.3 Mean Score and Standard Deviation in Post Test

The table 4.3 indicated the mean score of experimental class in the pos-ttest was 48.59 and the standard deviation 13.36. While the mean score of the controlled class was 35.52 and the standard deviation were 9.34 . 
Fatur Rahmah \& St. Nurjannah Yunus Tekeng, The Use of Scaffolding Talk Technique...

The standard deviation of students' post-test indicated that the mean score in this research seemed likely that it does not have good dispersion value because the standard deviation is 13.36 for experimental class and 9.34 for controlled class. On the other hand, the good dispersion value of mean score was if the result of standard deviation is under the grade of one $(<1)$. If the standard deviation was more or bigger than one, it showed that the value dispersion of mean score is quite bad.

Even though the standard deviation was not good enough, it can be concluded that the use of scaffolding talk technique is beneficial to improve the speaking skill of the students' because the mean score of students' post-test in experimental group is higher than the mean score of students' post-test in the controlled class.

\section{Test of Significance Testing}

The significant score between experimental and controlled class can be calculated by using t-test. The result of the t-test can be seen in table 4.4 as follows:

\begin{tabular}{|c||c||c|}
\hline Variable & t-test & t-table \\
\hline \hline $\mathrm{X}_{1} \mathrm{X}_{2}$ & 4.63 & 2.00 \\
\hline
\end{tabular}

Table 4.4 the t-test of students' achievement

Table 4.4 showed the result of test of significance testing. For the level of significance (p) 0, 05 and the degree of freedom $(\mathrm{df})\left(\mathrm{N}_{1}+\mathrm{N}_{2}\right)-2=(29+29)-2=56$, showed that the value of the t-test was higher than $\mathrm{t}$-table. The result of the test clearly showed that there was a significant difference between the students' score in the experimental and controlled class after the treatment of scaffolding talk technique. It indicated that the scaffolding talk technique was quite effective in improving students' speaking skill. It means the hypotesiscan accepted because the t-test was higher than t-table $(4.63>2.00)$. Hence, the hypothesis of the research was accepted.

\section{Discussion}

Scaffolding talk technique is a technique of learning in which students are given some assistance, guidance, supporting during the early stages of learning and then reduce the effort and provide an opportunity to the students or the students take over responsibility for an increasingly large after being unable to do it themselves. Analysis of the mean score gap in the post-test between the experimental and control ensures if the approach used was effective. The mean score of the experimental class was 48.59 and 35.52 for control class. It means the gap of the students' score of the experimental and control class is 13.07. The explanation of the gap between the two classes indicated that the experimental class showed high increasing than the control class while the controlled class scores were decreased.

To sum up, based on the the result of this study, which showed the students' scores were much higher after the treatment in experimental class using scaffolding talk 
technique, the use of scaffolding talk technique to improve their speaking skill especially for their fluency, accuracy and comprehensibility.

The findings above were in line with previous research findings. In Tika Rahmawati (2014)the result of the study emphasized that scaffolding talk techniquewas effective in enhancing the pre experimental group students' speaking skill in recount text. The findings showed that the students' speaking skill increases from pre to post test. Based on the Tika Rahmawati (2014) research, The mean of pre-test 47,08, the mean of post-test, 66,67. The $\mathrm{T}$-calculation is 3,18. The result showed that the T-calculation higher than T-table $(2,75)$. It means that Scaffolding Talk technique was able to improve the students' speaking skill. These activities may encourage students' motivation to focus on the text. The strategy encouraged students to be able to improve their speaking.

\section{CONCLUSION AND SUGGESTION}

\section{Conclusion}

Based on the result, the students' speaking skill effective by using scaffolding talk technique at the second grade student of MTs Madani Paopao. The findings showed that the improvement of the students' speaking skill is significant after the students got Scaffolding Talk technique. Based on the data of students' competence in experiment class was higher than controlled class. The t-test for both classes in post-test is 4.63 compared to the t-table with 2.00, since the score of t-test was larger than the score of t-table. It means that the scaffolding talk technique which was applied in the experimental class was effective to improve the students' speaking skill.

Scaffolding talk technique can improve the student's speaking skill at second grade students of MTs Madani Paopao. The Data analysis that the total score of students in experimental class in the posttest is 1409 and 1030 for control class. In addition, the mean score in posttest for experimental class is 48.59 and 35.52 for control class. The data showed that students' score in experimental class was higher than controlled class. It meant that scaffolding talk technique can improve the students speaking skill. Why scaffolding talk was effective to improve the speaking skill because this technique emphasize the use of English as the language model of interaction in all learning activities in English class. These results indicate that the scaffolding talk technique is more influential in students' ability to speak English.

\section{Suggestions}

In relation to the conclusion above, the researcher proposes the following offers:1). The teacher should find out the effective strategy in teaching speaking skill. 2) The students should be good learners; they should involve themselves in the classroom and pay attention to their teacher. 3) Student should have motivation in learning English. 4) The students should respect their teacher fully attention to the lesson for supporting the learning process 
Fatur Rahmah \& St. Nurjannah Yunus Tekeng, The Use of Scaffolding Talk Technique...

running well. 5). The teacher should use many alternative strategies in teaching speaking to improve students speaking skill. 6) The teacher should know the students difficulties in reading to help them so that they can solve their problem and get out from their difficulties. 7). The English teacher should be creative in developing teaching material and present the learning process enjoyable.

\section{BIBLIOGRAPHY}

Ali, Amelia. The Effectivenees of Guessing Games to Imrove The Students' Speaking Skill at The Second Year of SMP PPM Darul Falah Enrekang. Thessis. Makassar: UIN Alauddin Press . 2013 Arikunto, Suharsimi. Prosedur Penelitian: Suatu Pendekatan Praktik. Jakarta: Rinekacipta. 2013 Ayu Puspaning Tyas, Diah, Teachers Scaffolding Talks in Teaching Speaking (The Case of The Seventh Grade Teachers of SMP N 1 Jepara in The Academic Year of 2008/2009. Thesis. Universitas Negeri Semarang. 2009 http://lib.unnes.ac.id/1249/1/4844.pdf accessed 20 Januari 2016

Brown, H.D.. Language Assessment: Principles and Classroom Practices. White Plains, NY: Pearson Education. 2004

Cameron, Lyne. Teaching Language to Young Learners. Cambridge: Cambridge University Press. 2001 http://site.iugaza.edu.ps/akeshta/files/2010/02/class-discussion-PDFdocument1.pdf accessed 20 Januari 2016

Corden, Roy. Literacy and Learning Through Talk: Strategic to the Primary Classroom. Philadelphia: Open University Press. 2000.

Endah Tri Priyatni. Peningkatan Kompetensi Menulis Paragraf Dengan Teknik Scaffolding. Universitas Negeri Malang.

Fadliyah, Sry Rezky. The Effectiveness of Total Pshical Respons Through Imperative Sentences in Improving the Speaking Ability of the Second Grade Students at SMPN 1 Tanete Rilau Kab Barru. Thessis. Makassar.UIN Alauddin. 2013

Fauziati, Endang. Teaching of English as A Foreign Language (TEFL). Surakarta: Muhammadiyah University Press. 2005

Fitrianingrum, Arista. The Use of Three Steps Interview Technique to Improve Speaking Ability (A Classroom Action Research of the Ten Grade Students of SMK Informatika Nu Ungaran in the Academic Year of 2012/2013. Graduating Paper. Salatiga: 2013. http://perpus.iainsalatiga.ac.id/docfiles/abstraksi/62666328cc366cc3.pdf accessed 20 Januari 2016

Gay, etc.Educational Research: Competencies for Analysis and Applications. Edition. VIII: New Jersey: Pearson Education Inc, 2006.

Hornby, AS.1995. Oxford Advanced Learner's Dictionary. Oxford: Oxford University Press. 
Irfan. Increasing Students' Speaking SkillThrough Based Learning Strategy at Second Grade of MA AtTauffiq Lisu Barru. Thessis. Makassar.UIN Alauddin. 2008.

Jauhar, M. Implementasi Paikem dari Behavioristik sampai Konstruktivistik: sebuah pengembangan pembelajaran berbasis CTL (Contextual Teaching and Learning). Jakarta : Prestasi Pustaka. 2011

Klausmeier, H.J. Educationalexperience and cognitive development,Educational Psychologist, No. 12. 1977.

Latief, Adnan. Konstruktivisme dalam Pembelajaran Bahasa Inggris.Materi. Pelatiban Pembelajaran Kontekstual. 2002.

Mufidah, Ani Tsalisatul. "The Effectiveness of Role Play Method to Improve Students Speaking Skill in Transactional and Interpersonal Text (An Experimental Research of The Tenth Grade Students of MA Sultan Agung Blora in The Academic Year 2011/2012)”. Final Graduating Paper of English Education Department State Institute for Islamic Studies (STAIN) Salatiga. 2012

Mustari, Sri Hariati. The Utilizing of Three Step Interview in Improving Speaking Ability at the Second Year Students of Madrasah Aliyah Alauddin Madani Paopao. Thessis. Makassar. UIN Alauddin. 2014

Nunan, D. Language Teaching Methodology. London : Prentice Hall. 1991

Nur, Muzakkir. 'Improving The Students' Vocabulary by Using Tree Chart at The Second Year of Madrasah Aliyah Disamakan Palattae Kab. Bone”. Thesis. Makassar: Tarbiyah and Teaching Science Faculty UIN Alauddin, 2011.

Rahmawati, Tika. The Use of Scaffolding Talk Technique to Improve Students' Speaking Skill (Classroom Action Research of the Eighth Grade Students of MTs Negeri Andong in the Academic Year of 2013/2014) A Graduating Paper. STAIN Salatiga. 2014 http://perpus.iainsalatiga.ac.id/docfiles/fulltext/9724543369.pdf accessed 20 Januari 2016

Radjab,dkk. (2013). Improving Students' Speaking Skill Through Project Based Learning Technique At Class Iii-B Of Third Semester Students. Postgraduate Program of State University of Padang: Journal English Language Teaching (ELT)

Shanti, P. (2015). Developing Speaking Skills in English: Structural Competence versus Communicative Competence. Transactions on Engineering and Sciences

Rustam, Nur Afifah. The effectiveness of Project Based Learning effective to improve speaking skill of the second semester students of Cokroaminoto Palopo University. UIN Alauddin. 2016

Sugiyono.MetodePenelitianPendidikan: PendekatanKuantitatif,Kualitatif, dan R\&D.Cet. X; Bandung: Alfabeta, 2010.

Sukirman. The ability of the fifth semester Students of English Language and Literature Department at Alauddin Islam State University Makassar in Analyzing Sentence in Reading Text Using Cooperative Learning Graduating Paper. Makassar: UIN Alauddin.2010 
Fatur Rahmah \& St. Nurjannah Yunus Tekeng, The Use of Scaffolding Talk Technique...

Suriani. Improving The Students Speaking Ability Through Problems Based Learning Strategy at the Second Grade Students of SMPN 3 Bulupodda. Thesis. Makassar. Uin alauddin. 2013

Surtiati. Teachers' Scaffolding Talk in English Class at Senior High School. Unpublished Post Graduate Program. Semarang: State University Of Semarang. 2008 http://lib.unnes.ac.id/16807/1/2201504008.pdf accessed 20 Januari 2016

Syarif. Improving The Students' Speaking Ability of Second Grade Through Communicative Approach at Shekh Hasan Yamani Islamic Boarding School in Polman. UIN Alauddin Makassar. 2014.

Vygotsky, L. Mind in Society: The Development of Higher Psychological Process Cambridge. MA: Harvard University Press. 1978. http://home.fau.edu/musgrove/ web/vygotsky1978.pdf accessed 20 Januari 2016

Wood, D. Bruner, J.S. dan Ross, G. The Role of Titoring in Problem Solving. Jurnal of Child Pyschology and Psychiarty 89-100. Pergamon Press. 1976 http://isites.harvard.edu/fs/docs/icb.topic850552.files/Wood1976.pdf accessed 20 Januari 2016

Zulfiqar, Saidna. Teaching Speaking (English) Through Yahoo Messenger: Theory And $\begin{array}{llll}\text { Practice. Jakarta: } & \text { Qalam } & \end{array}$ https://books.google.co.id/books?id=X-

8LCAAAQBAJ\&pg $=\mathrm{PA} 10 \& \mathrm{lpg}=\mathrm{PA} 10 \& \mathrm{dq}=\mathrm{CLASSIFICATION}+\mathrm{SCORE}+\mathrm{OF}+\mathrm{S}$ PEAKING\&source $=$ bl\&ots $=$ LwavVUVVmX\&sig $=$ GXnOua4K4NJp1_FwSVAP8 MF4RKY\&hl=id\&sa $=$ X\&ved=0ahUKEwi6mK_-

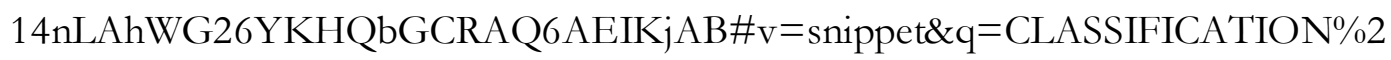
0SCORE $\% 20$ OF\%20SPEAKING\&f=false accessed 20 Januari 2016 